\title{
International Unit per Milliliter per Milligram per Kilogram per Day
}

National Cancer Institute

\section{Source}

National Cancer Institute. International Unit per Milliliter per Milligram per Kilogram per

Day. NCI Thesaurus. Code C119369.

A unit of concentration (biologic activity) equal to one international unit per milliliter,

divided by milligrams per kilogram per day. 